\title{
The Historical Development and Tasks of Liberal Arts Education in Korean universities
}

\section{Paek, Seungsu \\ Professor, Gachon University, ongang@gachon.ac.kr}

\section{Abstract}

Korean universities have sought sustainable future-oriented liberal arts education while exploring the role of liberal arts education in the era of the 4th industrial revolution. Even so, unresolved issues arising from historical development should be overcome to take a great step toward innovating liberal arts education. The purpose of this study is to identify problems that appeared in the historical development process of liberal arts education at Korean universities and to derive overcoming tasks. The historical development of liberal arts education at Korean universities can be divided into three stages: Formation Period (1945-1972), Experimental Period (1973-2009), and Autonomous Period (2010-present). The issues that emerged in this development process have two characteristics: confusion in the identity of liberal arts education and development through government control and support. For the sustainable future of liberal arts education, it is necessary to overcome misleading perceptions that hinder the realization of the true meaning of liberal arts education and establish the identity of liberal arts education. Universities should secure autonomy from the government and more actively strengthen and innovate liberal arts education.

Key Words: liberal arts education, history of liberal arts education in Korean, general education, higher education, government policy, University autonomy

1. Introduction

2. Historical Development of Liberal Arts Education in Korea

3. Characteristics of Liberal Arts Education in Korean Universities

4. Tasks of Liberal Arts Education in Korean Universities

5. Conclusions 


\section{Introduction}

Discourses on the crisis of university liberal arts education are not new. In the 1970s, scepticism regarding liberal arts education in universities started to grow, and criticism has been harsh with liberal arts education. Liberal education in university was even criticized that it "is out of touch, elitist, ineffective, too expensive, and well its use" (Logan \& Curry, 2015: 66). Until recently, there has been continuing public debate of the effectiveness of the liberal arts education (Cook, 2020; Gerber, 2020). However, such criticism has also provided an opportunity for deeper reflection and discussion on the liberal arts education, and has served as a turning point for improvements and innovation. There have been numerous efforts to improve liberal arts education (i.e. The Association of American Colleges and Universities, 2018), and positive signs of a revival in university liberal arts education have begun to appear. For instance, Georgetown University Centre on Education and the Workforce (2020) reveals that return on investment (ROI) of liberal arts colleges is higher than that of general higher education institutions (HEIs), which contrasts the previous argument that the economic benefit of Liberal Arts College is lower than that of general HEIs.

With the arrival of the digital age and the Fourth Industrial Revolution, the roles of higher education have been greatly emphasized (Gleason, 2018) and there has been a growing realization of the necessity for liberal arts education, and multiple measures have been proposed to extend such education. Accordingly, university liberal arts education has begun to take advantage of new opportunities. For instance, due to the growing awareness of the necessity and importance of improving liberal arts education in the era of the Fourth Industrial Revolution, European and Asian universities, which were relatively passive in developing liberal arts education in the past, have started to discuss improvements in liberal arts to respond to the digital age (Georgetown University Center on Education and the Workforce, 2020; Dirksen, Kontowski, \& Kretz, 2017; Van der Wende, 2011; Godwin \& Pickus,
2017; Zhao, 2017). Accordingly, the future global spread of liberal arts education is expected. In addition, there are a growing number of programs that reflect the characteristics of both the East and the West, such as Yale-NUS College, the liberal arts institution developed by Yale University in collaboration with the National University of Singapore (NUS) (Lewis, 2018). This program clearly demonstrates that liberal arts education is a global concern and of growing interest.

In Korea, there has been much discussion about the role of liberal arts education in the digital age (Paek, 2017; Son, 2016; Kim \& Won, 2018). Based on their accumulated liberal arts experience and capacity, Korean universities have made efforts to explore future-oriented liberal arts education. However, Korean universities have not been able to overcome certain limitations arising from their historical development. Such limitations have to be resolved in order to make a new leap forward in liberal arts education. Education in Korea is embedded in historical traditions and a deep academic heritage, wherein a form of liberal arts education that emphasized whole-person education and character building was traditionally pursued. Therefore, if universities in Korea improve their liberal arts education formed over the past 70 years and make good use of their potential capacities, then, after a transition period, Korea will make a great step toward innovating liberal arts education for the digital age.

The aims of this research were to explore the revival of university liberal arts education in Korea and to suggest future directions for liberal arts education in the $21 \mathrm{st}$ Century. This was achieved through an examination of the historical development of liberal arts education and the roles of government policies in the process of this development. 


\section{Historical Development of Liberal Arts Education in Korea}

\subsection{Historical Background}

A classical liberal arts education that was based on Confucian values was started at Taehak, the first higher education institution in Korea established in 372. The Joseon Dynasty, founded in 1392, reigned over the Korean peninsula through a system of civil governance based on Neo-Confucianism. By developing a national standard curriculum based on character building and a focus on Confucian classics, such as The Basic Learning, The Great Learning, Doctrine of the Mean, Analects and Mencius, the Joseon Dynasty institutionalized Confucian liberal arts education for several hundred years. This education centred around Sungkyunkwan, the foremost institution of higher learning, which was established in 1398.

At the end of the 19th Century, Joseon adopted a modern education system and planned to provide liberal arts education. However, in 1910, with the annexation of Korea, education came under the control of the Japanese colonial government. It is noteworthy that the current term liberal arts was introduced at this time. Imperial Japan introduced a reinterpreted form of liberal arts education based on the German concept of Bildung, or self-cultivation (Kang, 1995). Therefore, liberal arts education of that time was considered to be the preserve of aristocratic elites, and it carried a strong connotation of human formation, cultivation and the harmonious development of human capacities, all of which are integral to Bildung (Paek, 2019a).

\subsection{Development of Liberal Arts Education in Modern Korean Universities}

Following Korea's liberation from Japanese colonial rule in 1945, Korea entered the era of modern education. Since 1945, liberal arts education in Korea has gone through several stages of development. These historical developments can, in general, be classified into three stages.

\subsubsection{Formation Period of Liberal Arts Education in Korean Universities (1945-1972)}

Immediately following liberation in 1945, the Korean peninsula was divided into two nations, South Korea and North Korea, and the United States Military Government became the official ruling body of South Korea until 1948. The U.S. Military Government tried to reshape Korean education (Jung, 2018), and this included establishing Seoul National University and forming the basic framework of Korea's current education system. With regard to university-level liberal arts education, the U.S. Military Government introduced general education, a form of liberal arts education typical to the United States, as 교양 교육 (liberal arts education). That is, the general education introduced by the US Military Government was not called 일반교육 (general education) but was translated as 교양교 육 (liberal arts education). In Korea, 교양교육 continues to be called liberal arts education in Korean, but general education in English. It might be that the term 교양교육 (liberal arts education) was preferred to the term 일반교육 (general education), given that Korean society values the moral and cultural aspects of education (Lee, 1987). However, this confusing use of terminology has restricted the establishment of a specific identity for liberal arts education in Korea.

During this period, the foundation for Korean liberal arts education was laid down through several stages of legislation. Under the rules of the U.S. Military Government, the university curriculum was divided into compulsory, major, and elective subjects. Although the distinction between compulsory and elective subjects was made during the Japanese colonial era, the elective system at that time was not really 'elective' system because most elective courses are 'required' to complete to advance to the next level. With the introduction of a new system, 
a credit system, students could register for their desired classes, and two distinctive categories, 'required courses' and 'elective courses', became a basic principle of the university curriculum.

With the establishment of the Korean government in 1948, education policies that had previously been adopted during the U.S. Military Government period became embodied in statutes such as the Education Act (1949) and the Enforcement Decree of the Education Act (1952). In particular, the organization and completion of the general liberal arts curriculum were stipulated in detail in the Enforcement Decree of the Education Act of 1952 The key contents were as follows (Paek, 2019a): First, subjects, which had previously been classified into compulsory, major, and elective subjects, were now divided into compulsory and elective subjects, and compulsory subjects were further divided into general liberal arts subjects and major subjects. In other words, the Enforcement Decree of the Education Act structured subject classification by first stipulating curriculum completion requirements, namely the completion of both compulsory and elective subjects, and then stipulating the content of the general liberal arts curriculum and the major curriculum. Second, general liberal arts subjects were defined as subjects necessary to develop general leadership character, indicating the purpose of general liberal arts education. Third, the subjects that fell under the category of liberal arts education were stipulated and the distribution requirements system by academic division was adopted. Fourth, it was stipulated that elective subjects should be within one-third of the total curriculum, indicating the legalization of the elective curriculum. Fifth, it was stipulated that general liberal arts subjects should be no more than one-third of compulsory subjects, prescribing the total number of liberal arts subjects that could be taken. General liberal arts subjects, therefore, were officially introduced during the process of legalizing liberal arts education in the Enforcement Decree of the Education Act in 1952.

In 1953, the government revised the Enforcement Decree of the Education Act, stipulating, in greater detail, the content and completion standards of general liberal arts subjects (Paek, 2019a). First, six subjects, including Korean Language, Foreign Language, Introduction to Philosophy, Cultural History, Introduction to Natural Sciences, and Physical Education, were stipulated as compulsory liberal arts subjects in all universities. This had not been prescribed in the Enforcement Decree of the Education Act in 1952. Next, the number of subjects required to complete distribution requirements by academic division was reduced from three to one. Finally, it was stipulated that subjects which can belong to required courses, should not belong to elective courses, in order to prevent major subjects from infiltrating the liberal arts curriculum.

\subsubsection{Experimental Period of Liberal Arts Education in Korean Universities (1973-2009)}

The formation period of liberal arts education from 1945 to 1972 proposed a basic form of Korean liberal arts education that continues to exert influence today. At the same time, the government and universities have attempted to solve problems that emerged during the formation period of liberal arts education. From 1973 to 2009, two bold institutional experiments were carried out to change the paradigm of Korean university education. One was the pilot university system and the other was the university college system.

Pilot University System and Liberal Arts Education: Based on the Master Plan for Higher Education, announced in 1972, the government initiated a university education reform known as the Pilot University System in 1973. The objective was to improve the quality of university education by introducing an experimental university management system similar to that of educationally advanced countries, such as the United States. The pilot university system was not applied uniformly across the nation. Rather, under the principles of autonomous university reform, the recognition of flexibility in how education operates, and gradual reform, the pilot university system adopted a more gradual approach by selecting and supporting universities 
with the capability to implement autonomous reforms. Ten universities were selected for the pilot university system in 1973 and a further 43 were selected in 1980. Since 1981, all universities have carried out reforms through this system.

The pilot university system reform had an impact on liberal arts education. The biggest impact was the reduction in the number of credits required to graduate. In general, universities reduced the liberal arts curriculum by three credits (49 to 46 credits), the major curriculum by 13 credits (82 to 69 credits), and the elective curriculum by 4 credits (29 to 25 credits) (Lee, 1987). Universities attempted to make up for the reduction in credits in the major curriculum by changing the liberal arts curriculum. In other words, universities attempted to move credit courses that had previously been part of the major curriculum to the liberal arts curriculum. Prior to the emergence of the pilot university system, the liberal arts curriculum had been divided into compulsory and elective subjects. However, liberal arts elective subjects were replaced by basic major subjects, leading to the reclassification of the liberal arts curriculum into general liberal arts subjects and basic major subjects (Lee, 1989). As a result, areas that fell under the major curriculum, including major basics, common basics, academic division basics, and basic common became part of the liberal arts curriculum. This phenomenon of moving major subjects into the liberal arts curriculum became known as a Korean phenomenon and it continues to be common practice in universities today.

With the aim of improving the quality of university education and increasing the flexibility of academic systems, the pilot university system attempted to adopt the United States university system. However, some unexpected effects have been reported, such as a high concentration of students choosing popular majors after admission. The pilot university system was not the experimental scheme in leading areas, as originally intended, but a semi-coercive top-down reform on general areas across universities. It was the first policy initiative to apply the idea of the university college system as a means of opening up the closed department-centred system (Kang $\&$ Kim, 2010). Although the scope of liberal arts education has expanded, it has lost its original purpose and become a sub-concept of major education (Kim et al., 2001). Furthermore, in 1974, the government designated Civil Ethics, Physical Education, Military Drilling, and Korean History, all nationally required subjects designated by the government, as part of liberal arts education curriculum, causing identity distortion within liberal arts education. In 1989, all nationally required subjects were abolished.

The University College System and Liberal Arts Education: In 1995, the government implemented one of the most influential educational reforms in modern Korean history, the Education Reform Measure to Establish a New Education. This reform advocated open education based on the idea of neo-liberalism, with specialization and diversification of universities as policy goals. In order to cultivate talented graduates with qualities and abilities required in diverse sectors of society, the reforms introduced new university establishment regulations and the self-regulation of enrolment quotas. This led to the rapid quantitative expansion of Korean universities.

The university college system and the minimum major credit system introduced by the Educational Reform had a direct impact on liberal arts education. The university college system was designed to transform departmentoriented education into college-oriented education. For this purpose, admission systems also changed from the recruitment of freshman according to a department-based quota to recruitment according to a division/college-based quota. In addition, the minimum major credit system set a new number of minimum credit hours to be completed in the major program. The purpose of this change was to make it possible for students to conduct multidisciplinary and interdisciplinary studies outside the narrow confines of the department. By drastically reducing the number of major credits from one-quarter to one-sixth of the total number of credits required to graduate, students could complete two or more majors within four years.

Following the implementation of the university college 
system, most universities redesigned their curricula based on academic divisions and colleges, rather than based on a single department or major. As a result, liberal arts curricula were also redesigned based on academic divisions. In addition, a large number of the elective subjects requested by students, such as employment-related subjects and sports-related subjects, appeared in liberal arts curricula as consumer-driven courses.

Another important policy changed by the Enforcement Decree of the Education Act was the abolition of the regulation that liberal arts subjects should account for 30\% of total credits. Instead, universities could decide autonomously on the number of credits required for the completion of the liberal arts curriculum. As a result, liberal arts education in Korea completely broke free from legal control. This escape from a system in which the state had the right to control liberal arts education through laws and regulations was highly desirable given the increased autonomy for universities in Korea. However, by removing the legal requirements that secured the number of credit hours required to complete liberal arts subjects, universities began to reduce the number of liberal arts courses on offer.

In 2009, with the abolition of the mandatory university college system in the Higher Education Act, universities were no longer obliged to maintain the university college system and many universities opted to abolish it. Contrary to its original purpose of ensuring a wider range of major choices for students, the university college system had a number of negative side effects, such as weakening major education, the decline in students' sense of belonging to departments, the marginalization of basic academic disciplines, the decline in the popular department-oriented hierarchy, and overheated competition for credits in order to get into popular departments. The rise and fall of the university college system reconfirmed the power of the department-centered system in Korean universities. In relation to liberal arts education, the restructuring of academic disciplines based on the university college system led to the collapse of basic academic disciplines and the weakening of the academic foundation of liberal arts education.

\subsubsection{University Liberal Arts Education Autonomous Period (2010-present)}

The third period has been one of revival. Since the liberalization of education in 1995, there have been various movements to revitalize liberal arts education. Some meaningful activities include, but are not limited to, the implementation of accreditation programs by the Korean Council for University Education (hereafter, KCUE), the emergence of academic communities, such as the Korean Association of General Education and the Korea National Institute for General Education (hereafter, KONIGE), the pursuit of reform initiatives through government funding projects, such as ACE (Advancement of College Education) and CORE (initiative for COllege of humanities' Research and Education), and the spread of a standard model for basic liberal arts education.

The mood of liberal arts education autonomy has already been born since the 2000s. In 2001, KCUE, as part of the Academic Accreditation Evaluation System, conducted a comprehensive evaluation of liberal arts education in 165 four-year universities. The status of liberal arts education was examined and suggestions for further development were addressed, based on an evaluation of 38 categories in six areas, including educational goals, curricula, faculty, courses and assessment, condition of educational facilities, and improvement efforts and development plans (Noh, 2010). This evaluation reported that the goals of liberal arts education in universities are appropriate based on their clarity, response to current demands, and goal setting that reflects institutional characteristics. However, the design of liberal arts curricula received negative reviews because the host units lacked clarity and relevant departments tended to provide liberal arts courses that appeared to be introductory courses for major subjects. As a result, the liberal arts curriculum was considered part of the introductory curriculum for major subjects. Regarding the operation of courses, liberal arts education 
was highly dependent on part-time faculty members and the report of the evaluation suggested that more full-time or regular faculty members should teach in order to improve the quality of liberal arts education.

Although several issues were reported, this comprehensive evaluation had a positive impact on universities. Many began to make efforts to develop their liberal arts education programs. For example, some universities revised the liberal arts curriculum and set up institutions with exclusive responsibility for liberal arts education. These had a variety of names, including "University College", "College of Basic Education", "Liberal Arts College", "Institute for General Education", and "Humanitas College". In 2004, these liberal arts education institutions formed a nationwide network, the Korean Council for University General Education. In 2006, the Korean Association of General Education was founded and, in 2007, it began publication of the Korean Journal of General Education, which has expanded the horizons of liberal arts education. In 2011, the Korean government established the Korea National Institute for General Education(KONIGE) to stimulate liberal arts education in higher education institutions.

During the 1990s, following a discourse on the crisis in the humanities, various policies focusing on the humanities, together with financial support projects, made important contributions to the revitalization of university liberal arts education. As in other countries, an emphasis on practical employment-focused studies in Korea led to a reduction in the number of basic education and humanities courses available, leading to a sense of crisis in university liberal arts education. Because of this, the government has supported revitalization, including strengthening liberal arts education in compliance with the evaluation of university financial support projects. In particular, government funding projects have had a considerable impact on the development of liberal arts education in universities. Among these, the ACE project is considered to have contributed to both the humanities and to the promotion of basic liberal arts education. The ACE project, between 2010 and 2017, had greatly emphasized undergraduate programs focusing on quality of education and student learning outcomes with enhancing teaching and learning, encouraging extracurricular activities, and implementing competency-based education. Accordingly, individual universities paid attention to liberal arts education and started to reemphasize it by establishing liberal arts education institutes. The Korea National Institute for General Education was established as a part of revitalization of university liberal arts education during the ACE project period. The CORE project, which is devoted to strengthening the humanities, has proposed different development models, such as the global regional studies model, the humanities-based convergence model, and the advanced fundamental studies model, and it has provided opportunities for selected universities to develop programs that bring together these three models. In particular, the CORE project added a liberal arts model, which is exclusively to support liberal arts education. Two universities were selected, and these universities have developed new liberal arts education curricula. Although the CORE project was implemented in the relative short term and only a few universities had direct benefits, it encouraged many universities to emphasize liberal arts education as well as the humanities.

Particularly noteworthy is development and spread of the KONIGE's Standard Model for general education announced in 2016. KONIGE is distributing the model to universities across the country, using it as a criterion for consulting on general education. Here, general education in its broad meaning, is divided into basic education, general education in its narrow meaning, and cultivating education areas. The sub-categories of the basic education area are divided into critical thinking, information literacy, communication, mathematics and basic sciences. In the general education area, the distribution curriculum and core curriculum are suggested as options. The distributional program is divided into humanities, social sciences and natural sciences, which are traditional academic fields, and the core courses are set up in diverse areas of value: nature and science, technology, human nature and condition, cultural phenomena and modern civilization, social reality, 
〈Table 1〉 Historical development of liberal arts education in Korean universities

\begin{tabular}{|c|c|c|c|}
\hline Division & Period & Main Measures & Related Policies \\
\hline $\begin{array}{l}\text { Formation } \\
\text { Period }\end{array}$ & $\begin{array}{l}1945- \\
1972\end{array}$ & $\begin{array}{l}\text { Introduction of liberal arts } \\
\text { curriculum, Legalization of liberal } \\
\text { arts education }(1952,1953)\end{array}$ & $\begin{array}{l}\text { Liberal arts curriculum was first introduced by the U.S. Military Government. } \\
\text { Types of liberal arts curriculum, and the common requirement subjects, and } \\
\text { distribution requirements, were prescribed by statutes. }\end{array}$ \\
\hline \multirow[b]{2}{*}{$\begin{array}{l}\text { Experimental } \\
\text { Period }\end{array}$} & \multirow[b]{2}{*}{$\begin{array}{l}1973- \\
2009\end{array}$} & $\begin{array}{l}\text { Introduction of pilot university } \\
\text { system (1973) }\end{array}$ & $\begin{array}{l}\text { The number of credits required for graduation was reduced from } 160 \text { to } 140 \text {. } \\
\text { Major basics (academic division basics) were distributed as liberal arts } \\
\text { subjects. } \\
\text { Liberal arts education was regarded as introductory major subjects. }\end{array}$ \\
\hline & & $\begin{array}{l}\text { Introduction of university college } \\
\text { system (1995) }\end{array}$ & $\begin{array}{l}\text { The New University Establishment Regulations and self-regulation of } \\
\text { enrolment quota system were introduced. } \\
\text { The university college system and a new admission system, recruiting students } \\
\text { based on academic division and colleges, were implemented. } \\
\text { The minimum major credit system was adopted. }\end{array}$ \\
\hline \multirow{2}{*}{$\begin{array}{l}\text { Autonomous } \\
\text { Period }\end{array}$} & \multirow{2}{*}{$\begin{array}{c}2010- \\
\text { present }\end{array}$} & $\begin{array}{l}\text { Expansion of university funding } \\
\text { projects }(2010)\end{array}$ & $\begin{array}{l}\text { Large-scale government funding projects for universities, such as ACE, were } \\
\text { implemented. } \\
\text { Competency-based liberal arts education was introduced. }\end{array}$ \\
\hline & & $\begin{array}{l}\text { Establishment of Korean model of } \\
\text { liberal arts education (2016) }\end{array}$ & $\begin{array}{l}\text { Best practices and consulting services to build a Korean model of liberal } \\
\text { arts education by the National Institute of General Education have been widely } \\
\text { implemented. }\end{array}$ \\
\hline
\end{tabular}

human beings and moral reasoning. The cultivating area consists of physical experience, social experience, and First Year program. Standard Model is becoming a standard for general education design in Korean universities. Many contributions are made to correct distorted practices in the field. $<$ Table $1>$ presents the key characteristics in the historical development of liberal arts education in Korean universities.

\section{Characteristics of Liberal Arts Education in Korean Universities}

Among the issues that have emerged during the development of liberal arts education in Korean universities, the two most important are the establishment of a liberal arts education identity and government-controlled development. The section discusses these characteristics.

\subsection{Establishment of a Liberal Arts Education Identity}

There are multiple and overlapping perceptions of liberal arts education in Korea. These have accumulated in the development process from general education during the U.S. Military Government era to the pilot university system and the university college system later. Variously referred to as general education, basic education, elective education, and basic liberal arts education, liberal arts education is considered to consist of non-core academic subjects. To be specific, liberal arts education is regarded as general rather than professional education, basic rather than high-level or advanced education, and elective rather than required education. The ambiguity of these perceptions has led to a distorted view. Liberal arts education has been inappropriately perceived as unnecessary and extra, as introductory and preliminary, with weak discipline and low standards, and more similar to a hobby or common sense than to rigorous scholarship. As a result, professors offer the opportunity to teach liberal arts subjects to their young students or junior lecturers, and students do not take their liberal arts subjects seriously, often not even considering them to be genuine studies. In the major departments, liberal arts subjects are perceived as a stake to maintain a certain number of courses, and major education and basic major studies encroach upon liberal arts education, viewing it as a preliminary or basic study for the major curriculum (Yun, 2017). Recently, furthermore, practical employment-oriented education has been included in the liberal arts curriculum, leading to the further distortion of liberal arts education in universities. 
One of the best examples of dispelling ambiguity in the identity of liberal arts education is the inclusion of free elective courses in the liberal arts curriculum. In general, free elective courses are not typically separated within the liberal arts curriculum, although the liberal arts, major, and elective curricula are typically evenly distributed in the actual operation of the curriculum. However, an analysis of the liberal arts curricula in Korean universities (Paek, 2019b) found that most universities operate a separate 'general free elective area in liberal arts education' with characteristics of 'elective education' within the liberal arts curriculum. The general free elective area in liberal arts education is divided into nine sub-areas in some universities, with a minimum of 28 and a maximum of 347 subjects listed.

Assigning the general free elective course to the liberal arts curriculum has created several problems. For example, as a key factor hindering the normalization and advancement of liberal arts education, general free elective courses in liberal arts education have led to the distortion of the university curriculum. Fragmented knowledge, such as simple practice for finding employment or starting a business, the expansion of common sense and information on hobbies, are unsuitable university curriculum subjects, and they undermine the identity of liberal arts education. In addition, it has distorted registration systems, as too many students register for liberal arts subjects that are viewed as 'subjects easy to earn credits', 'subjects with less intense workloads', and 'subjects requiring little learning'. At the same time, advanced liberal arts subjects at the centre of academic disciplines have been cancelled due to a lack of students.

\subsection{Development Based on Government Control and Support}

Another characteristic is that, until recently, the government has controlled basic curriculum requirements and has provided policy support to strengthen liberal arts education. Since the beginning, liberal arts education in modern Korean universities has developed under the legal control of the government. Since the establishment of the Korean government, the liberal arts curriculum has been regulated by the Education Act and the Enforcement Decree of the Education Act. Therefore, the basic requirements of the liberal curriculum have been established and modified based on legal government guidelines rather than the regulations or policies of individual universities. The role of the government in liberal arts education has had both advantages and disadvantages. On the one hand, it has contributed to laying the foundation for liberal arts education in two ways. First, liberal arts education has had a role to play since the government established Korea's higher education system and, second, all universities are required by law to include liberal arts education in their curricula. However, on the other hand, the stipulation of the basic requirements of liberal arts education means that universities could not autonomously develop and operate their liberal arts education programs, and moreover, the isomorphic phenomenon has occurred because most universities have established similar liberal arts education systems. The total number and allocation of liberal arts education subjects in universities have been regulated by the government.

Over the past 70 years, the isomorphic phenomenon has been present in the goals, organization, content and operation of liberal arts education in Korean universities. It occurs through normative, coercive and mimetic processes (DiMaggio \& Powell, 1983), and liberal arts education in Korean universities is a form of coercive isomorphism based on the legal status of liberal arts education. Universities set similar goals, and divide the curriculum into similar areas, namely basic areas of study, distribution requirement areas, basic major areas, and free elective general education areas. The content generally consists of basic instrumental subjects and vocational and practical subjects, and an increasing number of universities have established institutions with exclusive responsibility for the operation of liberal arts education (An, Yoon, \& Han, 2020).

As legal control was abolished and universities secured 
autonomy, the government began to implement measures to support liberal arts education. The importance of liberal arts education was emphasized at the national level, and the strengthening of liberal arts education was included as an important criterion for determining eligibility for financial support. Therefore, plans to strengthen liberal arts education and the actual operation in universities were set as crucial indicators in large-scale funding projects, such as ACE or CORE projects. Government support for liberal arts education affected not only those universities selected by those projects, but also those preparing bids for the project, leading to the overall revitalization of liberal arts education in most Korean universities. In addition to providing financial support for universities, the government provided systematic support for university liberal arts education by establishing the Korea National Institute for General Education, a state-level institution dedicated exclusively to liberal arts education. The interplay between government support and universities provided an opportunity for the revival of liberal arts education in Korean universities.

\section{Tasks of Liberal Arts Education in Korean Universities}

The historical tasks of liberal arts education in Korean universities can also be analysed from two characteristics discussed previously. First, the most fundamental and difficult question in liberal arts education in Korea has been the establishment of its identity. As discussed earlier, problems, such as the multiple different terms used to refer to liberal arts education and the inclusion of non-liberal arts education subjects, such as general elective courses, have existed since its inception, causing confusion over its identity.

Despite long-standing criticism of these problems, few suitable solutions have been proposed. However, there have recently been discussions addressing these issues, and these are expected to continue. Paek (2019b), for instance, argues for the differentiation between liberal arts education and non-liberal arts education in Korea, in order to establish the identity of the former. The liberal arts curriculum should be oriented toward its original values, rather than practical and functional education, in order to match the intrinsic values of free education. To achieve this, the first priority should be to differentiate liberal arts education from hobby education and functional education for the purposes of employment. Hobby and common-sense subjects should not be called liberal arts education as they do not provide academic, universal, or core knowledge essential to the liberal arts. In other words, hobby and experience-related subjects, such as swimming, golf, and life style and health care, should not be offered as liberal arts education subjects as they reduce the quality of that education. Second, liberal arts education should be differentiated from employment preparation programs. Many people have misinterpreted the liberal arts curriculum as a process for developing professional skills. Office skills courses, such as Excel Basics and Its Utilization, PowerPoint and Photoshop, and functional courses for employment or start-up training, such as Strategy for Landing Jobs, Personal Development and Start-ups, and A Short-Term Company Internship should not be included in the university liberal arts curriculum as they only offer simple and practical employability skills. Simple skills and knowledge taught in employment and start-up training courses lack academic rigor and, therefore, should not be regarded as university liberal arts education. Thus, the establishment of an identity for liberal arts education such as the elimination of non-liberal arts subjects from the liberal arts curriculum is the first step toward sustainable development of liberal arts education in universities.

Another important way of enhancing sustainability of liberal arts education is the active engagement of professional community. As discussed earlier, until recently, the government uniformly controlled the design of the curriculum and the operation of programs through the legalization of liberal arts education. However, based on a recognition that liberal arts education should be strength- 
ened to respect university autonomy and to achieve development and innovation in higher education in the $21 \mathrm{st}$ Century, the government had provided financial support to strengthen it. Such innovative policy change is greatly enhancing the sustainability of liberal arts education. Nevertheless, the government no longer provides direct funding although liberal arts education is still emphasized when the government offers special financial support to universities. Without direct funding support from and regulatory control by the government, liberal arts education in the university needs to find its own way to not only maintain the programs but also proactively respond to the digital age. Fortunately, the positive sign enhancing the sustainability of liberal arts education is the active engagement of academic and practical communities by individual universities and professors in charge of liberal arts education. Over the past 10 years, most universities have established academic units and prepared operating systems dedicated to liberal arts education, and the Korean Association of General Education was established to form an academic community. In particular, the Korea National Institute for General Education and the Korean Association of General Education have jointly provided consultancy services for the development of liberal arts education in universities. This has strengthened the overall capacity of individual universities, and demonstrated the potential for all universities to develop together. In addition, professors and experts in the universities and professional communities play a critical role in the improvement of liberal arts education. For instance, An, Yoon, and Han (2020) insist that professor professionalism has a positive effect on liberal arts education in Korea. Hence, the active roles of professional communities that secure autonomy from the government are important for the sustainable future of liberal arts education in universities.

\section{Conclusions}

Liberal arts education aims to cultivate graduates and explore truth based on education free from ignorance and prejudice. Pursuing humanity, a good life, a desirable society, and human prosperity, liberal arts education contributes to promoting the spirit of human beings and enhancing society. In this respect, liberal arts education should be not only an intellectual education that extends the intellectual horizon, but a character building education that enhances human values and deepens our humanity. In particular, in order to become indispensable in the post-human era of the Fourth Industrial Revolution and the coevolution of AI (artificial intelligence) and HI (human intelligence), liberal arts education should strive to be continuously innovative. To sum up, liberal arts education should be an education that pursues "a better life" according to the changing times and the flow of civilizations, based on the universality of human culture and the human-specific higher spirit. At the same time, it should constantly strive to innovate for the future of higher education. In order to achieve sustainability, liberal arts education should not only reflect on itself, but also question whether it is devoted to familiarizing itself with the social order of democratic citizens and cultivating cultured people who seek truth through critical thinking. Liberal arts education, therefore, should always be universal.

The first step toward achieving universal liberal arts education is to critique and reflect on the current state of this form of education, with all stakeholders making an effort to develop liberal arts education. Currently, Korean universities are actively engaged in activities to make a new leap forward based on reflections on past developments. The government has transformed from the management and control of liberal arts education to providing support for strengthening liberal arts education in the digital era, while universities have transformed from imitative adoption and uncritical acceptance to pursuing autonomous innovation. More importantly, experts are attempting to normalize liberal arts education based on reflection. Such efforts made by key stakeholders are expected to contribute to the further development of liberal arts education in Korean universities. 


\section{References}

An, M. Y., Yoon, S., \& Han, S.-H.(2020). "The Effects of a professor's professionalism and diversity on the perception and satisfaction of education in the liberal arts curriculum", Sustainability 12, 3689.

Cook, N.(2010, April 4). "Jobs: The economy, killing liberal arts education?", Newsweek, Retrieved from https://www.ne wsweek.com/jobs-economy-killing-liberal-arts-education210090 (accessed on 31 August 2020).

DiMaggio, P. J., \& Powell, W. W.(1983). "The iron cage revisited institutional isomorphism and collective rationality in organizational fields", American Sociological Review 48, 147-160.

Dirksen, J. T., Kontowski, D., \& Kretz, D. (Eds.)(2017). What is Liberal Education and what could it be? LESC: Delphi, UK.

Georgetown University Centre on Education and the Workforce (2020). ROI of Liberal arts colleges: value adds up over time, Author.

Gerber, S.(2012, September 24). "How liberal arts colleges are failing America", The Atlantic. Retrieved from http://www.t heatlantic.com/business/archive/2012/09/how-liberal-arts-c olleges-are-failing-america/262711/ (accessed on 31 August 2020).

Gleason, N. W.(2018). Higher education in the era of the fourth Industrial revolution, Palgrave Macmillan, Singapore.

Godwin, K. A., \& Pickus, N. (Eds.)(2017). Liberal arts \& sciences innovation in China: six recommendations to shape the future, Boston College Centre for International Higher Education, MA, USA.

Jung, J.(2018). "Higher education in Korea: Western influences, Asian values and indigenous processes", Journal of Asian Public Policy 11(1), 1-13.

Kang, M., \& Kim, J. H.(2010). "The current status of undergraduate academic structure and problems of general education identity crisis in Korean universities", Asian Journal of Education 11, 327-361.

Kang, Y.-A.(1995). "The formation-background of philosophical terms used in Korea at present", Journal of Philosophical Ideas 5, 15-50.

Kim, J., \& Won, M.(2018). "The era of the fourth Industrial revolution and liberal arts as a platform", Journal of the Humanities 70, 211-213.

Kim, Y., Yoo, H., Lee, S., Jeon, J., Cho, K., Lee, H., Kim, K., \& Seo, D.(2001). A comprehensive report of the field of Liberal Art Education under the academic Program evaluation accreditation system in 2001, Korean Council for University Education, Seoul, Korea.

Lee, M.(1989). "A study on the improvement of university general Education Curriculum", The Journal of Educational Research 6, 19-27.

Lee, S.(1987). Theory of university Curriculum, Yonsei University Press, Seoul, Korea.

Lewis, P.(2018). "Globalizing the liberal arts: twenty-first-century education", In Higher education in the era of the fourth Industrial revolution (pp. 15-38), Palgrave Macmillan, Singapore. https://doi.org/10.1007/978-981-13-0194-0

Logan, J., \& Curry, J.(2015). “A Liberal Arts Education: Global Trends and Challenges", Christian Higher Education 14(2), 66-79. doi.org/10.1080/15363759.2015.973344

Noh, K. B.(2010). Policy proposal for the promotion of University Liberal art education. National Research Council for Economics, Humanities and Social Sciences, Seoul, Korea.

Paek, S. S.(2017). "Search for Direction of Liberal Arts Education in the era of the fourth Industrial Revolution", Korean Journal of General Education 11, 13-51.

Paek, S. S.(2019a). "Reconceptualization of general education through reestablishing appellation of general education", Korean Journal of General Education 13, 141-161.

Paek, S. S.(2019b). "A critical inquiry on the liberal arts education of the elective courses in Korean universities", Journal of Learner-Cantered Curriculum and Instruction 19, 903-922.

Son, D. H.(2006). "Liberal Art Education: A new horizons of higher education in Korea?", Proceeding on the annual conference of the Korean Association of General Education, June 24, 2016, Seoul, Korea, The Korean Association of General Education, 577-591.

The Association of American Colleges and Universities(2018). Fulfilling the American Dream: Liberal Education and the Future of Work. Washington, D.C.

Van der Wende, M.(2011). "The emergence of liberal arts and sciences education in Europe: A comparative perspective", Higher Education Policy 24, 233-253.

Yun, W.(2017). "The nature of University Liberal Art Education consulting: its purpose and content", Proceeding on the 2017 meeting on University Liberal Art Education consulting, March 24, 2017, Seoul, Korea, The Korean Association of General Education, 1-12.

Zhao, Y.(2017). "Reinventing liberal arts education in China in the age of smart machines", In Kara A. Godwin, \& Noah Pickus (Eds.), Liberal Arts \& Sciences Innovation in China: Six Recommendations to Shape the Future (pp. 23-33), Boston College Centre for International Higher Education. 


\section{한국 대학 교양교육의 역사적 전개와 과제}

\section{백승수}

가천대학교 교수

\section{초록}

한국의 대학들은 4차 산업혁명 시대의 교양교육의 역할에 대하여 탐구하면서 지속가능한 미래 지향적 교양교육을 모색해왔 다. 그렇지만 교양교육의 역사적 전개에서 비롯된 미해결 문제들을 극복해야만 교양교육 혁신의 큰 발걸음을 내딛을 수 있다. 이 연구의 목적은 한국 대학 교양교육의 역사적 전개 과정 상에 나타난 문제점을 규명하고 극복 과제를 도출하기 위한 것이다. 한국 대학 교양교육의 역사적 전개는 형성기(1945-1972), 실험기(1973-2009), 자율화기(2010-현재) 등 세 시기로 구분할 수 있다. 이 전개 과정에서 나타난 이슈는 교양교육의 정체성 혼란 문제와 정부의 통제와 지원에 의한 발전이라는 두 가지 특징을 가지고 있다. 교양교육의 지속가능한 미래를 위해서는 교양교육의 진정한 의미 구현을 저해하는 오도된 인식을 극복하고 교양교육의 정체성을 확립해야 한다. 대학들은 정부의 지원과 통제로부터의 자율성을 확보하고, 보다 적극적이 고 능동적으로 교양교육을 혁신하고 강화해 나가야 할 것이다.

주제어: 교양교육, 한국교양교육사, 일반교육, 고등교육, 정부 정책, 대학 자율성 